\title{
Mobilization, Cloning, and Sequence Determination of a Plasmid-Encoded Polygalacturonase from a Phytopathogenic Burkholderia (Pseudomonas) cepacia
}

\author{
Carlos F. Gonzalez, Elizabeth A. Pettit, Victoria A. Valadez, and Ellen M. Provin \\ Department of Plant Pathology and Microbiology, Texas A\&M University, College Station 77843-2132 U.S.A. \\ Received 28 January 1997. Accepted 24 June 1997.
}

\begin{abstract}
Phytopathogenic strains of Burkholderia cepacia (synonym Pseudomonas cepacia) produce endopolygalacturonase, whereas strains of clinical and soil origin do not. Growth of a phytopathogenic strain (ATCC25416) at elevated temperatures resulted in nonpectolytic derivatives that were either cured of a resident plasmid or contained a plasmid of reduced mass. The resident 200-kb plasmid (pPEC320) in strain ATCC25416 was tagged with Tn5-Mob. The pPEC320::Tn5-Mob (pPEC321) plasmid was mobilized in B. cepacia strains of soil and clinical origin. Transconjugants containing pPEC321 expressed the endopolygalacturonase and showed differential activity on plant tissue. No evidence for self-transfer of pPEC320 or the tagged derivative was observed. A $2.85-\mathrm{kb}$ cloned fragment from pPEC320 containing the plasmid-borne pehA gene was sequenced and compared to the pehA gene from Erwinia carotovora subsp. carotovora and Ralstonia solanacearum and the polygalacturonase sequence from Lycopersicon esculentum.
\end{abstract}

Additional keywords: Pseudomonas solanacearum, virulence factor.

Burkholderia cepacia (synonym Pseudomonas cepacia; Yabauuchi et al. 1992) is a highly versatile bacterium that has adapted to a number of different environments. It is the causal agent of decay of onions (Burkholder 1950), is an opportunistic pathogen of man (Conly et al. 1986; McKevitt and Woods 1984; Tablan et al. 1987), and is commonly found in soil environments (Ballard et al. 1970; McArthur et al. 1988). In a previous study by Gonzalez and Vidaver (1979), strains of B. cepacia of plant (BCP) and clinical (BCC) origins were compared. In Gonzalez and Vidaver's (1979) study, conventional biochemical tests and antibiotic sensitivity patterns supported synonymy between strains of $B$. cepacia, $P$. kingii, and $P$. multivorans. However, bacteriocin production patterns, onion maceration tests, and hydrolysis of low-pH pectate agar clearly differentiated $\mathrm{BCC}$ and $\mathrm{BCP}$ strains into two distinct

Corresponding author: C. F. Gonzalez: E-mail: cf-gonzalez@tamu.edu

Nucleotide and amino acid sequence data of the pehA gene are to be found at GenBank as accession number U85788. groups. The same study (Gonzalez and Vidaver 1979) found plasmid DNA in 15 of 16 strains examined. However, the role of the resident plasmids in the ecological fitness of the diverse B. cepacia was not determined. Lennon and DeCicco (1991) conducted a plasmid screen of $37 \mathrm{~B}$. cepacia isolates from clinical, pharmaceutical-industrial, and environmental origins and found that $84 \%$ of the strains examined contained plasmid DNA. However, no phenotypic attributes were assigned to the plasmids.

The unusual catabolic potential and wide distribution of $B$. cepacia in the environment suggest the possibility of novel mechanisms for the adaptability of this microorganism. Genetic studies have determined that one of the most important factors underlying the extraordinary adaptability and catabolic potential of $B$. cepacia may be the prevalence of insertion elements in its genome and associated plasmids (Lessie et al. 1990; Wood et al. 1990). A number of insertion sequences have been identified in B. cepacia based on their ability to promote genomic rearrangement (Beckman et al. 1982; Gaffney and Lessie 1987), to recruit foreign genes by replicon fusion (Barsomian and Lessie 1986), and to cause insertional activation of gene(s) (Scordilis et al. 1987). This genomic rearrangement presumably contributes to the adaptability of B. cepacia.

Phytopathogenic strains of $B$. cepacia have been implicated in both field and postharvest disease problems (Cother and Dowling 1985; Kawamoto and Lorbeer 1972, 1974). Plantpathogenic B. cepacia strains characteristically produce a polygalacturonase (Peh) that is responsible for the maceration of both bulb scale and leaf tissue and is implicated in disease development (Ulrich 1975). In the current study, we demonstrate the conjugal mobilization of a Peh-encoding plasmid, and the cloning and sequence analysis of the pehA (pectic enzyme hydrolase) gene from B. cepacia.

\section{RESULTS}

Selection for $\mathrm{Peh}^{-}$derivatives.

Phenotypically polygalacturonase negative $\left(\mathrm{Peh}^{-}\right)$derivatives of ATCC25416 (Table 1) were obtained by growing the strain at elevated temperatures. The $\mathrm{Peh}^{-}$derivatives were detected on Hildebrand's medium A (HA) (Hildebrand 1971) and were readily distinguishable from parental $\mathrm{Peh}^{+}$colonies that produced pitting. The frequency of $\mathrm{Peh}^{-}$derivatives ranged 
from 1 to $2 \%$ of colonies tested $(2,000)$ in four independent experiments. The plasmid content of the parental strain and the $\mathrm{Peh}^{-}$derivatives was examined to determine whether the $\mathrm{Peh}^{+}$phenotype was plasmid associated. The parental strain harbored a single plasmid of approximately $200 \mathrm{~kb}$ (Fig. 1, lane A). A plasmid survey of $20 \mathrm{Peh}^{-}$derivatives indicated that two classes of $\mathrm{Peh}^{-}$derivatives were obtained from the heat treatment. Strain BCP251 (Fig. 1, lane B) is representative of derivatives that are $\mathrm{Peh}^{-}$and contains a deletion of the resident plasmid, designated pPEC322. A second class of $\mathrm{Peh}^{-}$derivatives that shows no evidence of the resident plasmid is represented by strain BCP252 (Fig. 1, lane C). Of the $\mathrm{Peh}^{-}$derivatives examined, half harbored a plasmid of reduced mass, and half were cured of the resident plasmid. Restriction enzyme analysis of the parental plasmid (pPEC320) and the $\mathrm{Peh}^{-}$ derivative, pPEC322, confirmed a deletion of $35 \mathrm{~kb}$ (data not shown). Derivatives of ATCC25416 that harbored pPEC322 or no longer contained the Peh-encoding plasmid were unable to macerate plant tissue but were able to cause restricted necrosis of plant tissue at the site of inoculation.
Tagging and mobilization of the Peh-encoding plasmid.

Plasmid pPEC320 from strain ATCC25416 was tagged with the selective marker kanamycin $(\mathrm{Km})$, using the suicide plasmid pSUP5011, which contains Tn5-Mob. Tagging experiments yielded $\mathrm{Km}$-resistant $\left(\mathrm{Km}^{\mathrm{r}}\right)$ transconjugants at a frequency of $2 \times 10^{-6}$ per recipient. Conjugal mobilization of pPEC320::Tn5-Mob(pPEC321) was accomplished with plasmid pRK2013 in triparental matings. Strain BCP253 $\left(\mathrm{Peh}^{+}\right.$, catabolizes myo-inositol [ino ${ }^{+}$, does not catabolize itaconic acid $\left[\mathrm{ita}^{-}\right]$), a representative transposon-tagged derivative containing pPEC321, was used as the donor strain in a series of triparental crosses with $\mathrm{Peh}^{-}$, ino ${ }^{-}$, ita ${ }^{+}$, and trimethoprim-resistant $\left(\mathrm{Tp}^{\mathrm{r}}\right)$ recipient B. cepacia $\mathrm{BCS}$ or BCC strains (Table 1). Initial mobilization of pPEC321 into BCS or BCC strains of B. cepacia was detected at a frequency of $1 \times 10^{-6}$ to $6.2 \times 10^{-6}$ per recipient (Table 2). The BCS and BCC transconjugants expressed a $\mathrm{Peh}^{+}$, ino $^{-}$, ita $^{+}$, and $\mathrm{Tp}^{\mathrm{r}}$ phenotype and harbored plasmid pPEC321. Physical evidence for the presence of pPEC321 in the transconjugants was confirmed by agarose gel electrophoresis of survey lysates (data not shown) and Southern blot

Table 1. Bacterial strains and plasmids used in this study ${ }^{a}$

\begin{tabular}{|c|c|c|}
\hline Strain & Relevant characteristics & Source or Reference \\
\hline \multicolumn{3}{|l|}{ Escherichia coli } \\
\hline DH5 $\alpha$ MCR & $\begin{array}{l}\mathrm{F}^{-} m c r \mathrm{~A} \Delta(m r r-h s d \mathrm{RMS}-m c r \mathrm{BC}) \phi 80 \mathrm{~d} l a c \mathrm{Z} \Delta \mathrm{M} 15 \Delta(\text { lacZYA-arg } \mathrm{F}) \mathrm{U} 169 \\
\text { end } 1 \text { 1recA1 deo } \mathrm{R} \text { thi-1 sup } 44 \lambda^{-} \text {gyrA96 relA1 }\end{array}$ & Life Technologies, Gaithersburg, MD \\
\hline $\mathrm{C} 2110$ & $\mathrm{Nal}^{\mathrm{r}}$, polA & Stachel et al. 1985 \\
\hline HB101 & $\mathrm{F}^{-}, \operatorname{rec} \mathrm{A} 13$ & Boyer and Roulland-Dussoix 1969 \\
\hline Sm17-1 & Mobilizing strain & Simon et al. 1983 \\
\hline \multicolumn{3}{|c|}{ Burkholderia cepacia } \\
\hline ATCC25416 & Plant pathogen, contains plasmid pPEC320, $200 \mathrm{~kb}, \mathrm{Peh}^{+}$, ino $^{+}$, ita $^{-}$ & $\begin{array}{l}\text { American Type Culture Collection, } \\
\text { Rockville, MD }\end{array}$ \\
\hline BCP251 & Harbors pPEC322, a 165-kb derivative of pPEC320, $\mathrm{Peh}^{-}, \mathrm{ino}^{+}, \mathrm{ita}^{-}$ & This study \\
\hline BCP2511 & $\mathrm{Nal}^{\mathrm{r}}, \mathrm{BCP} 251$ & This study \\
\hline ВCР252 & Plasmid-free derivative of ATCC25416, $\mathrm{Peh}^{-}$, ino $^{+}$, ita $^{-}$ & This study \\
\hline ВCР2521 & $\mathrm{Nal}^{\mathrm{r}}, \mathrm{BCP} 252$ & This study \\
\hline BCP253 & ATCC25416,contains pPEC320::Tn 5-Mob, designated pPEC321 & This study \\
\hline TL249-2 & Soil isolate, plasmid-free, lys- $2, \mathrm{Peh}^{-}$, ino $^{-}$, ita $^{+}$ & Gaffney and Lessie 1987 \\
\hline $\mathrm{BCS} 10$ & $\mathrm{Tp}^{\mathrm{r}}, \mathrm{TL} 249-2$ & This study \\
\hline DBO1 & Soil isolate, $\mathrm{Peh}^{-}$, ino $^{-}$, ita $^{+}$ & Zylstra et al. 1989 \\
\hline $\mathrm{BSC} 20$ & $\mathrm{Tp}^{\mathrm{r}}, \mathrm{DBO} 1$ & This study \\
\hline B4648 & Clinical isolate, $\mathrm{Peh}^{-}, \mathrm{ino}^{-}, \mathrm{ita}^{+}$ & Gonzalez and Vidaver 1979 \\
\hline BCC10 & $\mathrm{Tp}^{\mathrm{r}}, \mathrm{B} 4648$ & This study \\
\hline B5912 & Clinical isolate, $\mathrm{Peh}^{-}, \mathrm{ino}^{-}, \mathrm{ita}^{+}$ & Gonzalez and Vidaver 1979 \\
\hline BCC11 & $\mathrm{Tp}^{\mathrm{r}}, \mathrm{B} 5912$ & This study \\
\hline \multicolumn{3}{|c|}{ Pseudomonas aeruginosa } \\
\hline $\mathrm{PAO} 25$ & $\arg \mathrm{F}$, leu-10, $\mathrm{Peh}^{-}$ & $\begin{array}{l}\text { R. H. Olsen, University of Michigan, } \\
\text { Ann Arbor }\end{array}$ \\
\hline \multicolumn{3}{|l|}{ Plasmids } \\
\hline pSUP5011 & Tn5-Mob vector, $\mathrm{Km}^{\mathrm{r}}$ & Simon 1984 \\
\hline pSUP2017 & $\mathrm{Tn} 7$ suicide vector, $\mathrm{Tp}^{\mathrm{r}}$ & Simon et al. 1983 \\
\hline pRK2013 & $\mathrm{Km}^{\mathrm{r}}, \mathrm{Tra}^{+}, \mathrm{Mob}^{+}$, ColE1 replicon & Figurski and Helinski 1979 \\
\hline pUFRO34 & $\mathrm{Inc} \mathrm{W}, \mathrm{Km}^{\mathrm{r}}, \mathrm{Mob}^{+}, \operatorname{mob}(\mathrm{P})$ lac $\mathrm{Z}^{+}, \mathrm{Par}^{+}$, cosmid & DeFeyter et al. 1990 \\
\hline pURFO47 & $\mathrm{Inc} \mathrm{W}, \mathrm{Amp}^{\mathrm{r}}, \mathrm{Gm}^{\mathrm{r}}, \mathrm{Mob}^{+}$, lac $\mathrm{Z}^{+}, \mathrm{Par}^{+}$, derivative of pURFO43 & DeFeyter and Gabriel 1991 \\
\hline pPEC323 & 5.3-kb SstI fragment from pPEC320 cloned in pUFRO34, $\mathrm{Peh}^{+}$ & This study \\
\hline pPEC 324 & 5.3-kb SstI fragment from pPEC320 cloned in pUFRO47, $\mathrm{Peh}^{+}$ & This study \\
\hline pPEC325 & 3.75-kb SstI-BamHI subclone of pPEC323 in pUFRO47, $\mathrm{Peh}^{+}$ & This study \\
\hline pPEC326 & 2.85-kb EcoRI-BamHI subclone of pPEC323 in pUFRO47, $\mathrm{Peh}^{+}$ & This study \\
\hline pHoKmGus & $\mathrm{Km}^{\mathrm{r}}, \mathrm{Ap}^{\mathrm{r}}$, tnpA ${ }^{-} ;$promoterless $\beta$-glucuronidase gene & Bonas et al. 1989 \\
\hline pSShe & $\mathrm{Cm}^{\mathrm{r}}, \operatorname{tnp} \mathrm{A}$ & Stachel et al. 1985 \\
\hline pRZ102 & ColE1::Tn5 & Jorgensen et al. 1979 \\
\hline
\end{tabular}

${ }^{a}$ Strains of plant, clinical, and soil origin have been designated with the prefix BCP, BCC, and BCS, respectively. $\mathrm{Nal}^{\mathrm{r}}, \mathrm{Tp}^{\mathrm{r}}, \mathrm{Ap}^{\mathrm{r}}, \mathrm{Gm}^{\mathrm{r}}$, and $\mathrm{Km}^{\mathrm{r}}=\mathrm{resis}$ tance to nalidixic acid, trimethoprim, ampicillin, gentamicin, and kanamycin, respectively. Peh $=$ polygalacturonase phenotype. Ino and ita $=$ ability to catabolize myo-inositol and itaconic acid. + and $-=$ positive and negative for phenotype, respectively. 
analysis of the same gel with a radiolabeled Tn5 probe (Fig. 2). Strain BCP253 (Fig. 2, lane B) and transconjugants containing plasmid pPEC321 showed hybridization to Tn5 (Fig. 2, lanes H, J, and L), whereas ATCC25416 (Fig. 2, lane A) and the respective recipient strains showed no hybridization to the probe (Fig 2, lanes G, I, and K). Transconjugants BCS101 and BCS201 (Table 2) obtained in the initial mobilization experiments subsequently were used as donors in triparental matings. The frequency of mobilization observed in this series of matings ranged from $1 \times 10^{-5}$ to $1 \times 10^{-4}$ transconjugants per recipient (Table 2). The transconjugants expressed the $\mathrm{Peh}^{+}$phenotype and harbored pPEC321. The absence of pPEC321 in the recipients and its presence in the transconjugants was confirmed further by lack of homology to $\operatorname{Tn} 5$ by the former (Fig. 2, lanes C and E) and homology by the respective transconjugants (Fig. 2, lanes D and F). No evidence for conjugal transfer of pPEC321 was observed in the absence of the mobilizing plasmid.

Supernatants from the parental recipient strains grown in M9GP medium (M9 medium supplemented with glycerol, polygalacturonic acid, and amino acids as required [Sambrook et al. 1989]) showed no Peh activity (Fig. 3, B1 to F1), whereas supernatants of their respective transconjugants harboring pPEC321, grown under the same conditions, showed Peh activity (Fig. 3, B2 to F2). Strain ATCC25416 produced a single polygalacturonase with a $\mathrm{pI}$ of 8.1 (Fig. 4, lane A). Isoelectric focusing (IEF) of culture supernatants from BCP253 and transconjugants harboring pPEC321 showed that they also produced a Peh with the same $\mathrm{pI}$ as that produced by ATCC25416 (Fig. 4, lanes B, C, and D). Supernatants from BCP251, BCP252, and the parental recipient strains, BCS10 and BCS20, grown

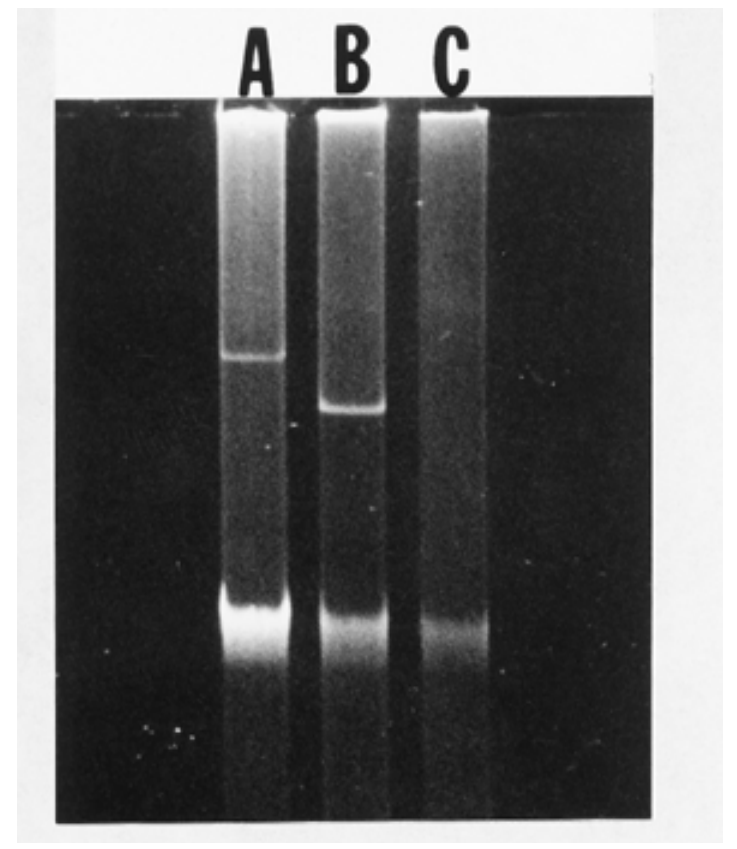

Fig. 1. Agarose gel electrophoresis of survey lysates from Burkholderia cepacia ATCC25416 and derivative strains. Lane A, ATCC25416; lane B, BCP251; and lane C, BCP252. Electrophoresis of DNA was in 0.7\% agarose at $40 \mathrm{~V}$ for $20 \mathrm{~h}$. The upper bands in lanes A and B represent plasmid DNA. The lower bands in lanes A and B represent chromosomal DNA and trapped linear plasmid DNA. The band in lane C represents chromosomal DNA. under the same conditions, showed no Peh activity (data not shown).

\section{Plant tissue inoculations.}

None of the unwounded bulb scales inoculated with the strains tested (Table 3) showed any symptom development during a 72-h period. The inoculum droplet remained on the surface of the epidermal layer, and the pathogen was unable to penetrate the layer. Wounded bulb scales inoculated with ATCC25416 showed a large zone of macerated tissue (Table 3). The plasmid-cured derivative (BCP252) produced no maceration but did produce necrosis that expanded during the test period. The clinical strain (BCC10) produced necrosis of plant tissue only at the higher inoculum concentration (Table 3). However, BCC101 did cause maceration of plant tissue at both levels of inoculation (Table 3 ). The symptoms elaborated by BCC101 were shot-hole in appearance, whereas those produced by ATCC25416 were a general maceration of tissue. Plant tissue inoculated with the soil strain, BCS20 or the derivative harboring the Peh-encoding plasmid (BCS201), exhibited no necrosis or maceration symptoms (Table 3 ).

\section{Enzyme activity.}

Examination of hydrolytic products by thin-layer chromatography (TLC) demonstrated the ability of the Peh from $B$. cepacia to release dimers $\left(\mathrm{R}_{f}=0.67\right)$, trimers $\left(\mathrm{R}_{f}=0.47\right)$, and larger oligomers $\left(\mathrm{R}_{f}=0.30\right)$ of galacturonic acid. The control exo-poly- $\alpha$-D-galacturonidase from Erwinia chrysanthemi generated dimers $\left(\mathrm{R}_{f}=0.60\right)$, whereas the endo-Peh from Agrobacterium vitis generated dimers $\left(\mathrm{R}_{f}=0.63\right)$, trimers $\left(\mathrm{R}_{f}=0.43\right)$, and larger oligomers of galacturonic acid $\left(\mathrm{R}_{f}=0.27\right)$. Viscometry assays with equivalent units of each enzyme showed the ability of the Peh from B. cepacia and the endo-Peh from $A$. vitis to rapidly reduce viscosity compared to the slower acting exo-cleaving enzyme from $E$. chrysanthemi. Cell extracts of ATCC25416 grown in M9 medium containing polygalacturonate exhibited a 7.5-fold increase in Peh activity compared to those grown in M-9 glucose. Extracellular Peh activity was fivefold higher in cells grown in the presence of polygalacturonate compared to glucose-grown cells.

\section{Cloning and expression of the pehA-encoding gene.}

An SstI library of plasmid pPEC320 was constructed in cosmid pUFRO34 and transfected into Escherichia coli DH5 $\alpha$ MCR (Table 1). The cosmid clones were mobilized into B. cepacia strain DBO1, a $\mathrm{Peh}^{-} \mathrm{BCS}$ strain, and transcon-

Table 2. Conjugal mobilization of plasmid pPEC321 in Burkholderia cepacia strains

\begin{tabular}{|c|c|c|c|}
\hline $\begin{array}{l}\text { Donor } \\
\text { strain }\end{array}$ & $\begin{array}{l}\text { Recipient } \\
\text { strain }\end{array}$ & $\begin{array}{l}\text { Transfer frequency/ } \\
\text { recipient }^{\mathrm{a}}\end{array}$ & $\begin{array}{c}\text { Transconjugant } \\
\text { designation }^{\mathrm{b}}\end{array}$ \\
\hline ВCP253 & BCS10 & $2.0 \times 10^{-6}$ & BCS101 \\
\hline BCP253 & BCS20 & $1.0 \times 10^{-6}$ & BCS201 \\
\hline ВСР253 & $\mathrm{BCC} 10$ & $6.2 \times 10^{-6}$ & BCC101 \\
\hline ВСР253 & BCC11 & $1.5 \times 10^{-6}$ & BCC111 \\
\hline BCS101 & BCP2511 & $1.0 \times 10^{-4}$ & BCP25111 \\
\hline BCS101 & ВСР2521 & $4.2 \times 10^{-5}$ & ВСР 25211 \\
\hline BCS101 & BCC10 & $7.5 \times 10^{-5}$ & BCC 102 \\
\hline BCS201 & BCP2521 & $1.0 \times 10^{-5}$ & BCP25212 \\
\hline
\end{tabular}

${ }^{a}$ Frequency is the average of three independent triparental matings, using pRK2013 as the mobilizing plasmid.

${ }^{b}$ All transconjugants contained pPEC321 and expressed a $\mathrm{Peh}^{+}$phenotype. 
jugants were assayed for Peh production on HA medium. Polygalacturonase activity was detected in an isolate harboring a cosmid (designated pPEC323) containing a 5.3-kb DNA fragment. The 5.3-kb fragment was subcloned as $3.75-\mathrm{kb} S s t \mathrm{I}-$ BamHI and 2.85-kb EcoRI-BamHI (Fig. 5) fragments into plasmid pUFR047, designated pPEC325 and pPEC326, respectively. Transconjugants of BCS20 and BCP252 that contained the subclones exhibited Peh activity on HA medium and produced Peh in M9GP medium. IEF of supernatant concentrates revealed a single activity band with a $\mathrm{pI}$ of 8.1 (data not shown). Cosmid pPEC324 (5.3-kb fragment in cosmid pUFRO47) also was mobilized in $P$. aeruginosa (Table 1) to determine expression of pehA in a heterologous background. Strain PAO25(pPEC324) grew on HA medium supplemented with leucine and arginine but did not pit the medium. Culture supernatants of PAO25(pPEC324) grown in supplemented M9GP medium exhibited no Peh activity, as determined by the pectate gel assay method. However, the osmotic shock fluid of PAO25(pPEC324) cells grown in M9GP medium exhibited Peh activity when assayed by the same method. Supernatants of PAO25, BCP251, and BCP252 grown and analyzed under the same conditions showed no Peh activity.

\section{Sequence of the pehA gene from B. cepacia.}

The nucleotide sequence of the 2.85-kb EcoRI-BamHI fragment contained in pPEC325 that expressed Peh activity was determined by sequencing both strands. The portion of the se-

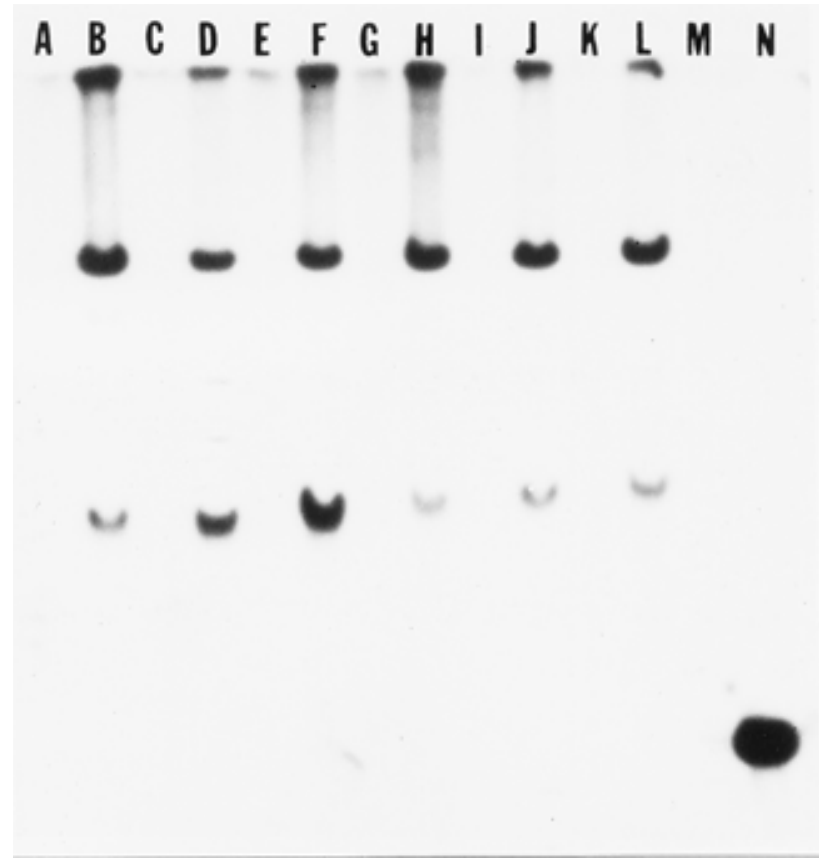

Fig. 2. Southern hybridization analysis of DNA from survey lysates of Burkholderia cepacia, donor, recipients, and transconjugant strains probed with Tn5. Lane A, ATCC25416; lane B, BCP253; lane C, BCP2511; lane D, BCP25111; lane E, BCP2521; lane F, BCP25212; lane G, BCS20; lane H, BCS201; lane I, BCS10; lane J, BCS101; lane K, BCC10; lane L, BCC101; lane M, blank; and lane N, probe plasmid pRZ102(Tn5). The upper bands represent plasmid DNA. The lower bands represent linear plasmid DNA trapped in chromosomal DNA of survey lysates. quence shown (Fig. 6) includes restriction sites that correspond to those designated in Figure 5. A consensus sequence (ATAGGTTA) for a Pseudomonas promoter (Mermod et al. 1984) was observed 63 bases upstream of the open reading frame (ORF) of the pehA sequence, suggesting a monocistronic operon. A possible ribosome-binding site was identified 4 bases upstream of the ATG translation initiation codon. The 459-amino acid ORF coded for a protein with a molecular mass of 46,260 Daltons. The translation stop codon TGA at position 1468 was followed by a putative transcription termination loop centered at position 1593. The loop was not followed by a polyT chain, suggesting the termination of transcription of pehA may be rho dependent. A putative signal sequence of 26 amino acids also was observed, beginning with the Met (position 1) and extending to Ala. The sequence contained a positively charged $\mathrm{N}$-terminal region, a central hydrophobic region (12 hydrophobic residues), and a polar carboxyl-terminal region that may define a cleavage site. An individual comparison of the amino acid sequences of the predicted pehA product from B. cepacia to that of the pehA gene products from $E$. carotovora subsp. carotovora and Ralstonia solanacearum (previously $P$. solanacearum, reclassified as B. solanacearum, and recently reclassified as $R$. solanacearum; Yabauuchi et al. 1992, $1995)$ and the polygalacturonase amino acid sequence from Lycopersicon esculentum (PG-2a) was done by the BESTFIT program (University of Wisconsin Genetics Computer Group; Devereux et al. 1984). The amino acid sequence from $B$. cepacia showed $30.3,25.4$, and $27.6 \%$ identity to the sequences from $E$. carotovora subsp. carotovora, $R$. solanacearum, and L. esculentum, respectively. Figure 7 shows an alignment of the four amino acid sequences by the PILEUP program (University of Wisconsin Genetics Computer Group). Several regions of high similarity or identity were observed when sequences were aligned. A 9-residue sequence, GXG(T/A)I(D/N)GXG, at positions 178 to 185 and a $10-$

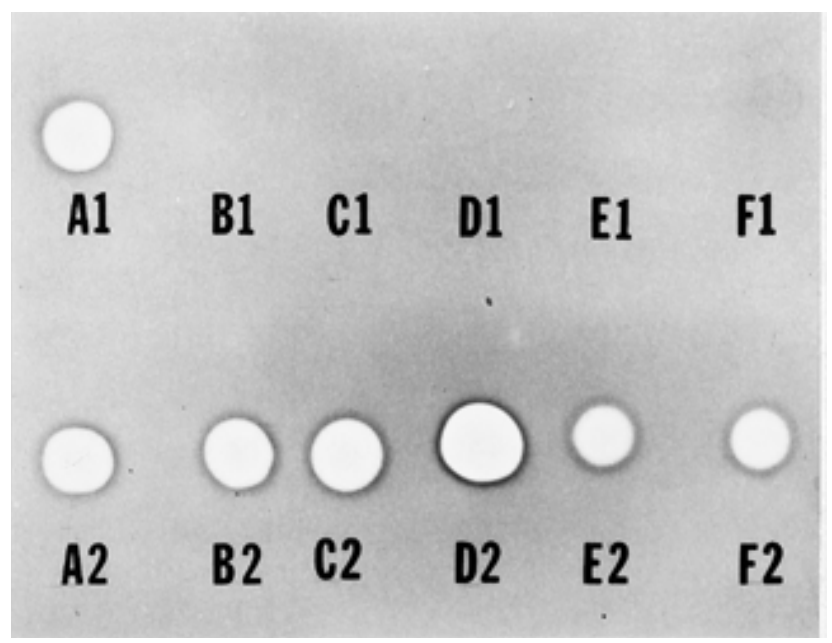

Fig. 3. Detection of polygalacturonase (Peh) activity in culture filtrates of Burkholderia cepacia ATCC25416 and donor, recipient, and transconjugant strains by the pectate-agar gel method: A1, ATCC25416; B1, BCP2511; C1, BCP2521; D1, BCS10; E1, BCS20; and F1, BCC10. B1 to $\mathrm{F} 1$ represent culture filtrates of $\mathrm{Peh}^{-}$recipient strains. A2 represents activity from BCP253 filtrates. B2 to F2 represent cultural filtrate activities of transconjugants of strains B1 to F1, which harbor plasmid pPEC321, respectively. Gel was stained with ruthenium red to detect activity. A clear zone indicates activity. 
residue sequence, (I/L)XTGDDX(V/I)(A/S)(I/V), at positions 322 to 331 appeared to be highly conserved. The sequences GHGXSIGS, GXRIK(S/T), and NTD located at positions 353 to 360,393 to 398 , and 301 to 303 , respectively, also showed a high degree of identical or conserved residues.

\section{Site-directed mutagenesis of the Peh-encoding plasmid.}

Mutagenesis of the 3.75-kb Sst-BamHI fragment contained in pPEC 325, which included the sequenced 2.85-kb EcoRIBamHI, was performed with the pHoKmGus transposon-reporter gene construct. Analysis of the mutants showed the same direction of transcription of pehA as that established by sequencing. The BCS20 transconjugants harboring the interrupted pehA gene between the $\mathrm{DraI}$ and the $B g l \mathrm{I}$ sites (Fig. 5) did not produce Peh in HA or M9GP medium (data not shown). Insertions 160, 155, and 82 exhibited normal pitting of HA medium (Fig. 5), whereas insert 50 showed reduced activity (Fig. 5).

It was of further interest to determine whether the Peh-encoding plasmid was transfer proficient. To examine this, three pHoKmGus (Fig. 5, number 23, 28, and 150) insertions of pPEC325 that exhibited a $\mathrm{Peh}^{-}$phenotype were marker-exchanged into plasmid pPEC320 harbored by strain ATCC25416 and confirmed by survey lysates and Southern blot analysis of plasmid DNA (data not shown). The derivative plasmids were designated pPEC $320,-23,-28$, and -150 , respectively. The $\mathrm{Km}^{\mathrm{r}}$, gentamicin-sensitive $\left(\mathrm{Gm}^{\mathrm{s}}\right)$ mutants showed no expression of Peh activity on HA medium and did not produce Peh

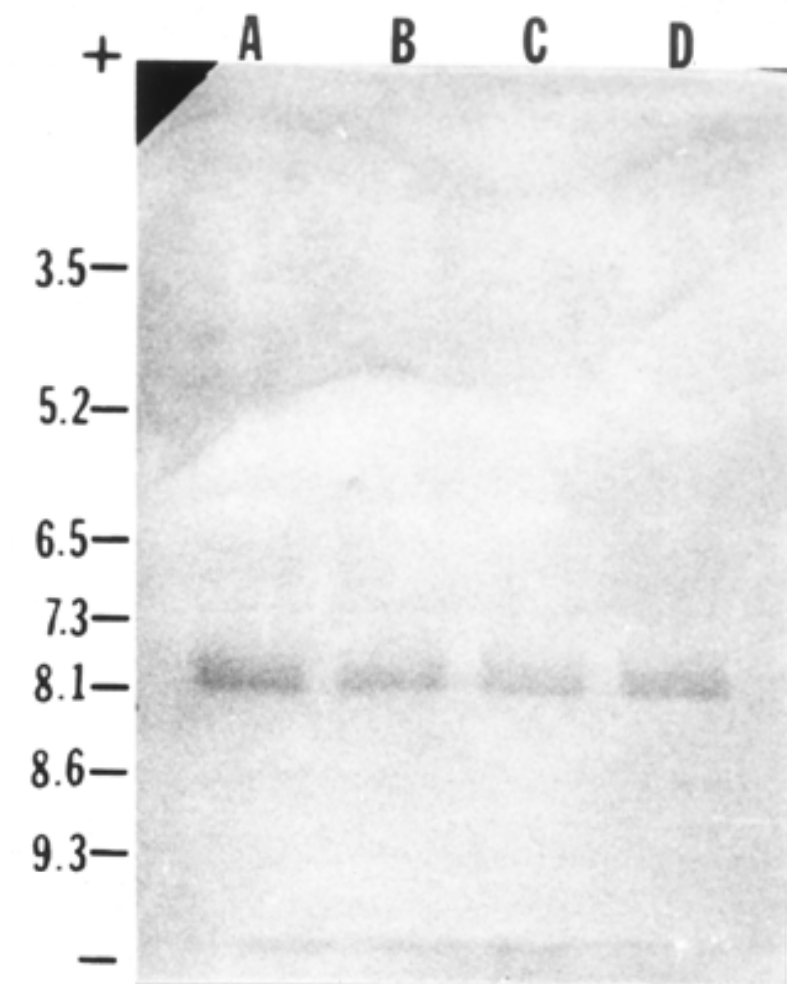

Fig. 4. Isoelectric focusing gel ( $\mathrm{pH} 3$ to 10) of extracellular proteins from Burkholderia cepacia ATCC 25416 and transconjugant strains containing the polygalacturonase-encoding plasmid pPEC321. Lane A, ATCC25416; lane B, BCP253; lane C, BCS101; and lane D, BCS201. pI markers and anode and cathode are indicated to the left of the gel. The pectate-agarose overlay was stained with hexadecyltrimethylammonium to detect activity. in liquid M9GP medium or macerate plant tissue. However, plant tissue inoculated with the mutants did exhibit the same symptoms of limited necrosis observed with BCP251 and BCP252. Because plasmid pPEC321 had shown no evidence of self-transfer, the possibility existed that the Tn5-Mob had inserted in a region of the plasmid that altered transfer functions. Strains containing the site-directed mutation of pPEC320 (pPEC320, 23, -28, or -150) in the pehA gene allowed testing of self-transfer without concern for the interruption of transfer functions, if present. No evidence for self-transfer was detected for plasmids pPEC $320,-23,-28$, or -150 in conjugal matings with both isogenic and nonisogenic strains of $B$. cepacia.

\section{DISCUSSION}

The role of pectic enzymes in the pathogenesis of plant pathogens is well established (Collmer and Keen 1986; Collmer et al. 1990). Some Erwinia and Pseudomonas species are able to incite soft rot or tissue maceration in a variety of plants (Collmer et al. 1990). In bacterial systems, the pectic enzymes of the soft-rotting Erwinia spp. are the most well characterized (Collmer and Keen 1986; Collmer et al. 1990). Erwinia spp. produce several classes of pectate enzymes, including pectate lyase, exopoly-galacturonate lyase, polygalacturonase, and exo-poly- $\alpha$-Dgalacturonosidase (Collmer and Keen 1986; Collmer et al. 1990). The nonfluorescent phytopathogenic pseudomonads $B$. cepacia, B. caryophylli, B. gladioli, and $R$. solanacearum all produce polygalacturonase (Gross and Cody 1985). Ulrich (1975) purified and characterized the pectolytic enzymes from B. cepacia and found that polygalacturonase was the principle enzyme produced during infection and that it had a $\mathrm{pH}$ optimum between 4.4 and 4.6. Infection of onion tissue resulted in tissue degradation and a lowering of the $\mathrm{pH}$ from 5.5 (healthy tissue) to near 4.0, which is conducive to polygalacturonase activity.

Evidence presented in this study demonstrates that the structural gene encoding for the production of polygalacturonase by ATCC25416, a phytopathogenic strain of B. cepacia, is plasmid determined. Growth of ATCC25416 under inducing and noninducing conditions indicates that production of Peh is regulated. Our current studies have not elucidated whether a hydrolytic product, presumably made by the basal level of Peh, is responsible for induction of Peh, as has been observed in other systems (Barras et al. 1994). Tagging of the Peh-encoding plasmid with Tn5-Mob allowed mobilization of plasmid pPEC321 into non-Peh-producing strains of B. cepacia of

Table 3. Onion tissue maceration and/or necrosis by Burkholderia cepacia strains

\begin{tabular}{lcc}
\hline & \multicolumn{2}{c}{ Inoculum (CFU/bulb scale) } \\
\cline { 2 - 3 } Strain & $\mathbf{1 0}^{\mathbf{3}}$ & $\mathbf{1 0}^{\mathbf{5}}$ \\
\hline ATCC25416 & $26 \pm 3.2^{\mathrm{a}, \mathrm{b}}$ & $29 \pm 4^{\mathrm{a}, \mathrm{b}}$ \\
BCP252 & $8.3 \pm 1^{\mathrm{c}}$ & $10.3 \pm 2^{\mathrm{c}}$ \\
BCC10 & $0^{\mathrm{a}, \mathrm{c}}$ & $7.7 \pm 1.1^{\mathrm{c}}$ \\
BCC101 & $9.5 \pm 3^{\mathrm{a}, \mathrm{b}}$ & $16 \pm 5^{\mathrm{a}, \mathrm{b}}$ \\
BCS20 & $0^{\mathrm{a}, \mathrm{c}}$ & $0^{\mathrm{a}, \mathrm{c}}$ \\
BCS201 & $0^{\mathrm{a}, \mathrm{c}}$ & $0^{\mathrm{a}, \mathrm{c}}$ \\
\hline
\end{tabular}

${ }^{a}$ Number indicates the average macerating diameter (in centimeters) plus/ minus the standard deviation at $48 \mathrm{~h}$ for four replicates.

${ }^{\mathrm{b}}$ No necrosis was measurable due to masking by tissue maceration.

${ }^{\mathrm{c}}$ Number indicates the average necrosis diameter (in centimeters) plus/ minus the standard deviation at $48 \mathrm{~h}$ for four replicates. 
plant, soil, and clinical origin. The transconjugants containing plasmid pPEC321 expressed a $\mathrm{Peh}^{+}$phenotype (Fig. 3), produced a single polygalacturonase with a $\mathrm{pI}$ of 8.1 (Fig. 4), and acted as donors in subsequent mobilization experiments (Table 2). The gene encoding the enzyme (pehA) was isolated from a cosmid library of plasmid pPEC 320 and expressed and secreted in both isogenic and nonisogenic strains of $B$. cepacia. Derivatives of ATCC25416 that were cured of the Peh-encoding plasmid (pPEC320), harbored the deleted plasmid pPEC322, or had an inactive pehA gene obtained by transposon mutagenesis were unable to macerate plant tissue but caused limited necrosis of plant tissue surrounding the point of inoculation. The plasmid-borne pehA gene, therefore, encoded for an extracellular enzyme that enhanced the aggressiveness of the pathogen in wounded tissue, because in the absence of Peh production the pathogen appeared to be restricted in its ability to cause extensive tissue damage (Table 3 ). We observed no disease development or necrosis of bulb scales in the absence of tissue wounding with any of the strains tested, confirming that $B$. cepacia is a wound pathogen, as had been observed by Kawamoto and Lorbeer (1974). The presence of the Peh-encoding plasmid enhanced the aggressiveness of ATCC25416 and clinical strain BCC101, which showed limited tissue necrosis without the plasmid. Introduction of the Peh-encoding plasmid into the BCS strain resulted in in vitro production of the enzyme but did not impart the ability to cause symptoms (Table 3), suggesting that the Peh enhanced virulence and the BCS strain lacked the primary determinant(s) required for pathogenesis. The role of the necrosis factor in pathogenicity awaits construction of mutants lacking this function.

Studies to examine expression of the B. cepacia pehA gene in heterologous backgrounds, such as $P$. aeruginosa, showed that the B. cepacia pehA gene was expressed. Osmotic shock experiments showed that the shock fluid had Peh activity, indicating a periplasmic location of the enzyme. Huang and Schell (1990) suggested that export of the polygalacturonase from $R$. solanacearum may be a two-step process, in which the Peh polypeptide first enters the periplasm before it crosses the outer membrane. The ability of the $P$. aeruginosa transconjugants to secrete the polygalacturonase into the periplasmic space suggests that the proposed 26-amino acid signal pep- tide of the $B$. cepacia polygalacturonase is recognized by $P$. aeruginosa. The positively charged N-terminal, central hydrophobic, and C-terminal regions are indicative of a signal sequence (von Heijne 1985). In addition, the predicted cleavage site for the signal sequence adheres to the " $(-3,-1)$-rule" as defined by von Heijne (1986). However, because the enzyme is not exported through the outer membrane, it is possible that $P$. aeruginosa lacks the enzyme export trait found in many soft-rotting Erwinia and Pseudomonas spp. (Murata et al. 1990; Salmond 1994). Enzyme export is tightly linked to the ability of various plant pathogens to cause disease, and in Erwinia spp., the Out gene cluster is essential for secretion of the major pectate lyases, polygalacturonases, and cellulases (Barras et al. 1994).

The pehA gene product expressed by B. cepacia appeared to have different biophysical properties from that reported for $E$. carotovora subsp. carotovora and $R$. solanacearum. The former has a $\mathrm{pI}$ of 10.19 and a $\mathrm{pH}$ optimum of 5.5, whereas the latter may produce at least two extracellular Peh enzymes, with the major one having a $\mathrm{pI}$ of 9.0 and a $\mathrm{pH}$ optimum of 5.7 and the minor one a pI of 8.0 (Allen et al. 1991; Schell et al. 1988). The pehA gene is located chromosomally in both E. carotovora subsp. carotovora (Willis et al. 1987) and $R$. solanacearum (Allen et al. 1991; Huang and Schell 1990). In Erwinia spp., the endo- and exo-PG are ancillary to the multiple pectate lyases produced (Collmer and Keen 1986; Collmer et al. 1990). In the case of $R$. solanacearum, the pehA gene product is important but not required for pathogenesis (Allen et al. 1991; Schell et al. 1988). The Peh produced by B. cepacia has a $\mathrm{pI}$ of 8.1 , has a $\mathrm{pH}$ optimum of 4.5 , is an endo-cleaving polygalacturonase (based on examination of hydrolytic products by TLC and viscometry assays), and appears to be a virulence factor. Although there are some biophysical differences that are apparent among the pehA products of E. carotovora subsp. carotovora, $R$. solanacearum, and B. cepacia, an amino acid sequence alignment (Fig. 7) showed several highly conserved regions in all three bacterial Peh's and PG-2a from tomato. Analysis of known polygalacturonases from several sources suggested that conserved sequences in the enzyme are required for activity. The histidine residue in the GHGXSIGS sequence (residues 353 to 360 ), the three aspartic acid resi-

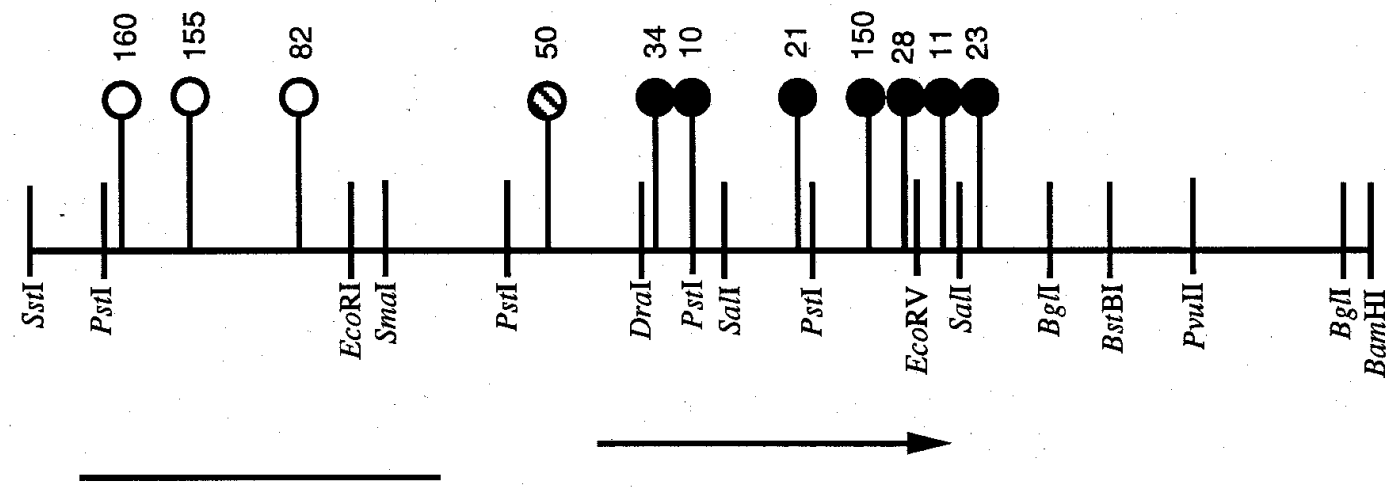

$1 \mathrm{~kb}$

Fig. 5. Physical map of the 3.75-kb SstI-BamHI fragment containing the pehA gene cloned from plasmid pPEC320. Solid and cross-hatched circles represent pHoKmGus insertions of plasmid pPEC325 that resulted in polygalacturonase negative $\left(\mathrm{Peh}^{-}\right)$mutants or mutants with reduced activity, respectively, as determined in Burkholderia cepacia strain BCS20. The open circles represent insertions that are Peh ${ }^{+}$The arrow indicates the transcriptional direction of the $p e h A$ gene. Restriction sites are indicated. 
dues in NTD (residues 303 to 305) and TGDD (residues 324 to 327 ), the RIK sequence (residues 395 to 397 ), and the tyrosine residue at position 431 all have been implicated in the activity of Peh enzyme from different sources (Bussink et al. 1991; Cooke et al. 1976; Stratilova et al. 1996). The recently published amino acid sequence of the pehA gene from Agrobacterium vitis (Herlache et al. 1997) also shows these same conserved sequences, which have been implicated in the activity of the Peh enzyme from diverse backgrounds.

Transposon mutagenesis of cosmid pPEC325 aided in the

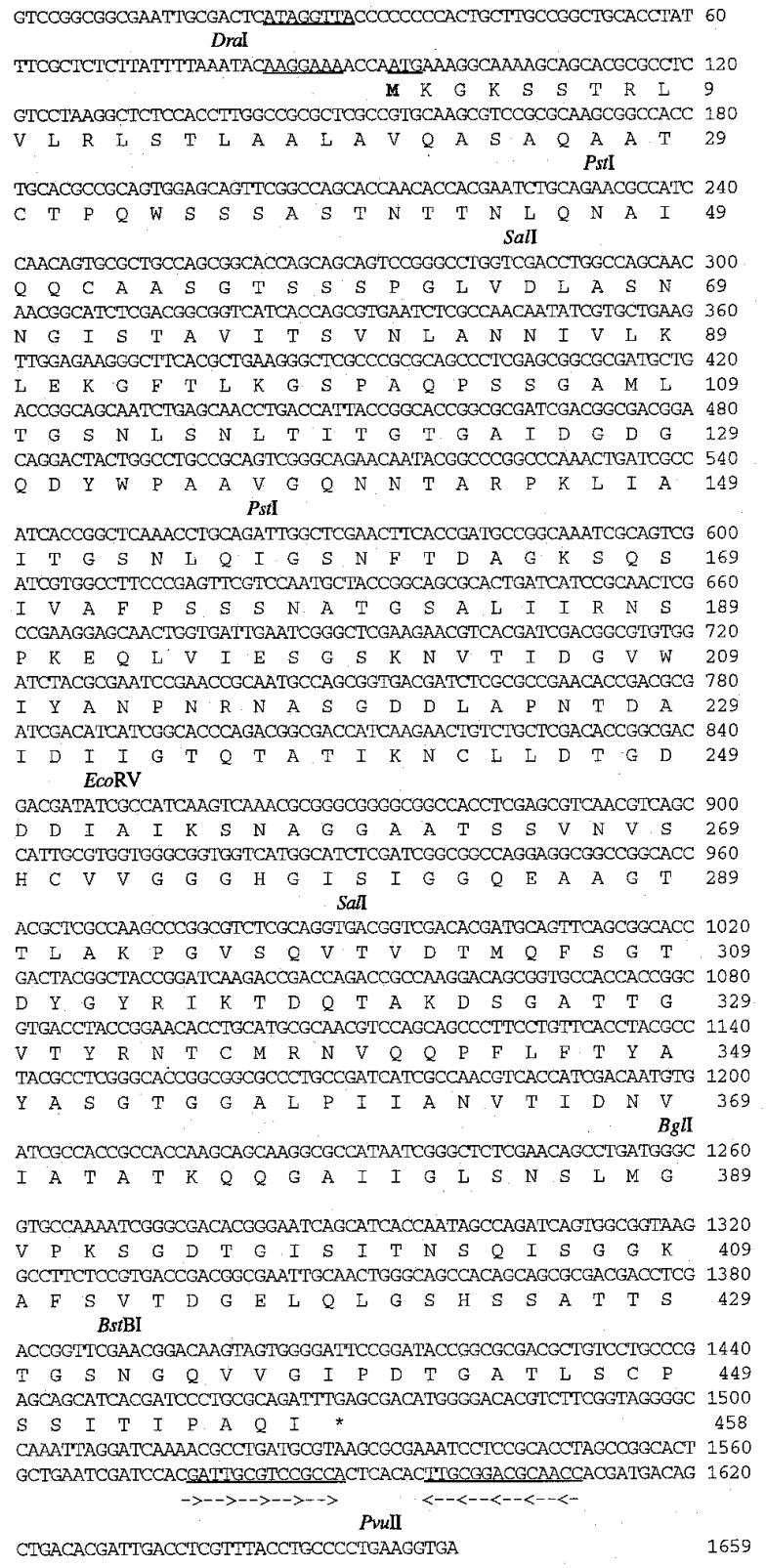

Fig. 6. DNA sequence of the pehA gene from Burkholderia cepacia and the predicted amino acid sequence. Underlined are the putative promoter sequence, the Shine-Delgarno sequence, and the translation start codon. The translation termination codon is indicated by an asterisk. A potential transcription termination loop is underlined and marked with arrows. The restriction sites are indicated. further characterization of the pehA gene and resulted in insertions useful for site-directed mutagenesis of plasmid pPEC320. Interruptions within the established pehA sequence resulted in loss of activity (Fig. 5). Insertion 50 (Fig. 5) in the pPEC325 clone was 210 base pairs upstream of the putative promoter for $p e h A$ and resulted in reduction in pitting activity. Because there is no significant ORF in the region, the observed reduction in activity is difficult to explain. Cosmid pPEC326 contains the $2.85-\mathrm{kb}$ fragment from plasmid pPEC320 that encodes for the production of Peh. Homology to the 2.85-kb Peh-encoding fragment was observed in plasmids from eight wildtype B. cepacia strains expressing Peh activity by Southern blot analysis (C. F. Gonzalez, unpublished data). This homology indicates that the plasmid-borne pehA gene may be widely distributed in phytopathogenic B. cepacia. Our study, using Tn5-Mob-tagged pPEC320 plasmid (pPEC321) and the transposon-tagged $\mathrm{Peh}^{-}$mutants (pPEC320, -23, -28, and -150), suggests that pPEC320 is not transfer proficient. However, it is possible that other plasmids containing a homologous pehA sequence may be transfer proficient.

In summary, we have identified a $200-\mathrm{kb}$ plasmid that encodes for Peh production in B. cepacia. Mobilization of the tagged plasmid or the cloned $2.85-\mathrm{kb}$ fragment containing the pehA gene from pPEC320 imparts the ability to produce an endo-Peh to naturally occurring $\mathrm{Peh}^{-}$B. cepacia of clinical or soil origin and restores the phenotype to $\mathrm{Peh}^{-}$derivatives of a phytopathogenic strain. Peh activity, a virulence factor, is the only phenotypic characteristic that currently has been associated with the plasmid. To our knowledge, this is the first report of a plasmid-encoded polygalacturonase.

\section{MATERIALS AND METHODS}

\section{Bacterial strains and plasmids.}

The bacterial strains and plasmids used in this study are listed in Table 1. B. cepacia strains of plant, clinical, and soil origin are designated with the prefix $\mathrm{BCP}, \mathrm{BCC}$, and $\mathrm{BCS}$, respectively.

\section{Media and growth conditions.}

Complex TN medium (Hansen and Olsen 1978) was used for routine maintenance of cultures. Minimal Vogel-Bonner glucose (VBG) medium (Vogel and Bonner 1965) was used in mating experiments. All media were supplemented with amino acids $(0.50 \mathrm{mM})$ as required. Antibiotics were added to media at the following concentrations: Tp at $50 \mu \mathrm{g} / \mathrm{ml}, \mathrm{Km}$ at 600 $\mu \mathrm{g} / \mathrm{ml}, \mathrm{Gm}$ at $100 \mu \mathrm{g} / \mathrm{ml}$, and nalidixic acid (Nal) at $500 \mu \mathrm{g} / \mathrm{ml}$ for B. cepacia; $\mathrm{Gm}$ at $100 \mu \mathrm{g} / \mathrm{ml}$ for $P$. aeruginosa; and ampicillin at $40 \mu \mathrm{g} / \mathrm{ml}, \mathrm{Gm}$ at $5 \mu \mathrm{g} / \mathrm{ml}$, and $\mathrm{Km} 25$ at $\mu \mathrm{g} / \mathrm{ml}$ for $E$. coli. All antibiotics were purchased from Sigma Chemical Co., St. Louis. M9 medium (Sambrook et al. 1989), adjusted to $\mathrm{pH}$ 5.0 and supplemented with $0.05 \%$ glycerol, $0.20 \%$ polygalacturonic acid, and amino acids as required (medium M9GP) was used to test for production of Peh in liquid medium. To determine carbon source utilization, the medium of Bochner and Savageau (1977) was used with either itaconic (BSI medium) or myo-inositol (BSM medium) added as the carbon source at a final concentration of $0.01 \%$. Phytopathogenic $B$. cepacia were routinely incubated at $28^{\circ} \mathrm{C}$ unless otherwise stated. Soil and clinical strains of B. cepacia, P. aeruginosa, and $E$. coli were incubated at $37^{\circ} \mathrm{C}$. 
ECC $\quad \ldots \ldots \ldots \ldots$. . . MEYQ SGKRVLSLSL GLIGLFSASA WASDSRTVSE

RS MNHRYTLLAL AAAALSAGAH ATGTSVTAPW GEVAEPSLPA DSAVCKTLSA

BC $\ldots \ldots \ldots \ldots \ldots \ldots \ldots \ldots \ldots$. . . . . . . .

PG-2a ......MVI QRNSILLLII IEASSISTCR SNVIDDNLFK QVYD.NILEQ

51

100

ECC PKTP.....S SCTTLKADSS TATSTIQKAL NNCDQ.... GKAVRLSAGS

RS SITPIKGSVD SVDGNPANSQ PDASRIQSAI DNCPA..... GQAVKLVKGS

BC TCTPQWSSSA $\mathbf{S} \ldots \ldots \ldots$ TNTTNLQNAI QQCAASGTSS SPGLVDLASN

PG-2a EFAHDFQAYL SYLSKNIESN NNIDKVDKNG IKVINVLSFG AKGDGKTYDN

$101 \quad 150$

ECC T..SVFLSGP LSLPSGVSLL IDKG...... VTLRAVNNA KSFENAPSSC

RS AGESGFLSGS LKLKSGVTLW IDTG...... .VTLFASRNP ADYDNGLGTC

BC NGISTAVITS VNLANNIVLK LEKG .......FTLKGS . . . . . . . .

PG-2a IAFEQAWNEA CSSRTPVQFV VPKNKNYLLK QITFSGPCRS SISVKIFGSI

1512200

ECC G.VVDKNG.K GCDAFITAVS TTNSGIYGPG TIDGQGGVKL . . . QDKKVS

Rs GTATTSND.K SCNALIVARD TAGSGIVGAG AIDGRGGSLV TSGPNANRLT

BC .....PAQ.P SSGAMLTGSN LSNLTITGTG AIDGDGQDYW PAAVGONNTA PG-2a EASSKISDYK DRRLWIAFDS VQNLVVGGGG TINGNGQVWW PSSCKINKSL

2012.250

ECC WWELAADAKV K......KL KQNTPRLIQI NKSKNFTLYN VSLINSPNFH

RS WWDIAYLNKT K......GL NQONPRLIQT YNGSAFTLYG VTVONSPNFH

BC RPKLIAITGS NLQIGSNFTD AGKSOSIVAF PSSSNATGSA LITRNSPKEO

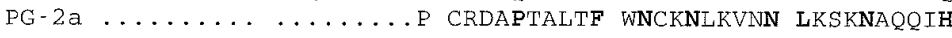

251

ECC VVF SDGDGF TAWTTMITTP S..............................

RS 251 TVC.

RS IVT.TGTSGV TAWGIKIVTP SLAYAVAGYK CPSGSTPDKV TPATCFTPET

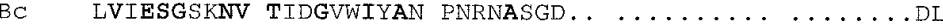

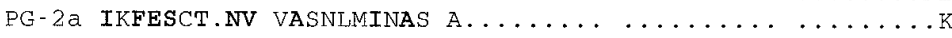

$301 \quad 350$

ECC ARNTDGIDPM SSKNITIAYS NIATGDDNVA IKAYKGRAET RNISILHNDF

RS VKNTDGFDPG QSTNVVLAYS YINTGDDHVA VKASSGP. . R RNLEFAHNHF

BC APNTDAIDII GTQTATIKNC LIDTGDDDIA IKSNAGGAAT SSVNVSHCVV

FG-2a SPNTDGVHVS NTQYIQISDT IIGTGDDCIS IVSGSQNVQA TNITC....

351

ECC GTGHGMSIGS E......T. MGVYNVTVDD LKMNG...T TNGLRIKSDK

Rs YYGHGLSIGS E......TN TGVSNMLVTD LTMDGNDSSA GNGLRIKSDA

BC GGGHGISIGG QEAAGTTLAK PGVSQVTVDT MQFSG.... T DYGYRIKTDO

PG-2a GPGHGISIGS ...LGSGNSE AYVSNVTVNE AKIIG.... A ENGVRIKTWQ

$401 \quad 450$

ECC SA. AGVVNG VRYSNVVMKN VAKPIVIDTV YEKKEGSNVP DWSDITFK. .

RS SR. .GGKVTN IVYDGICMRN VKEPLVFDPF YSSVKGSLYP NFTNIVVKNF

BC TAKDSGATTG VTYRNTCMRN VQQPFLFTYA YASGTGGALP IIANVTIDN.

PG-2a GG..SGQASN IKFLNVEMQD VKYPIIIDQN YCDRVEPCIQ QFSAVQVKNV

451

ECC .DVTSE.... . TKGVVVLNG ENAKKPIEVT MKNVKLTSD. STWQIKNVNV

RS HDLGSAKSIK RTMTFLGYKA NKOKNPLTIT LDNVVFDGTL PAFEGSHYGG

BC $\ldots \ldots \ldots \ldots \ldots$.....VIATA TKQQGAIIGI SNSLMGVPKS GDTGISITNS

PG-2a V.YENIKGTS ATKVAIKFDC STNFPCEGII MENINIVGES GKPSEATCKN

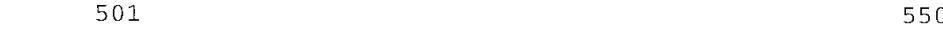

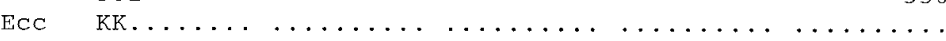

RS PASPNGVHFT FGGTGPVSFA DAIVTSSTTD VTVTGTPGTA AAVDCSKAFV

BC OISGGKAFSV TDGELQLGSH SSATTSTGSN GQVVGIPDTG ATLSCPSSIT

PG-2a VHFNNAEHVT PHCTSLEISE DEALLYNY...............

\begin{tabular}{|c|c|}
\hline & 551 \\
\hline $\mathrm{ECC}$ & $\ldots \ldots \ldots$ \\
\hline RS & PLKSVAPTSP \\
\hline $\mathrm{BC}$ & IPAQI $\ldots$. \\
\hline$P G-2 a$ & $\ldots \ldots \ldots$ \\
\hline
\end{tabular}

Fig. 7. Alignment of the predicted amino acid sequence of the pehA gene from Erwinia carotovora subsp. carotovora (Ecc) (Saarilahti et al. 1990), Ralstonia solanacearum (Rs) (Huang and Schell 1990), Burkholderia cepacia (Bc), and polygalacturonase from Lycopersicon esculentum (PG-2a) (Grierson et al. 1986; Bird et al. 1988), using the algorithm PILEUP program (University of Wisconsin Genetics Computer Group; Devereux et al. 1984). Identical amino acids are indicated in bold. 


\section{Plasmid elimination.}

The culture was grown for $18 \mathrm{~h}$ at $28^{\circ} \mathrm{C}$ in $\mathrm{TN}$ broth with shaking (200 rpm; model 4710, Queue Systems, Parkersburg, $\mathrm{WV})$. The cells were subcultured into prewarmed TN broth $\left(42^{\circ} \mathrm{C}\right)$ to a final concentration of $10^{4} \mathrm{CFU} / \mathrm{ml}$ and grown with shaking (200 rpm; model G76, New Brunswick Scientific Co., Inc., Edison, NJ) in a water bath at $42^{\circ} \mathrm{C}$ for $18 \mathrm{~h}$. Temperature-treated cultures were diluted and plated to TN agar. Individual colonies from the treatment were transferred to TN agar (stock culture) and stab-inoculated on HA medium (Hildebrand 1971) to test for pectolytic activity (pitting). Isolated colonies expressing a polygalacturonase negative $\left(\mathrm{Peh}^{-}\right)$ phenotype were purified by streaking on TN agar, and the individual colonies were retested on HA medium. Individual colonies reconfirmed as $\mathrm{Peh}^{-}$were subjected to further analysis.

\section{Transposon labeling and matings.}

Donor strain S17-1(pSUP5011) was used for tagging plasmid pPEC320, as described by Simon (1984). The filters were incubated at $37^{\circ} \mathrm{C}$ for $18 \mathrm{~h}$, washed in phosphate buffer $(0.01 \mathrm{M}$, $\mathrm{pH} 7.1)$, and plated to VBG medium containing $\mathrm{Km}(600 \mu \mathrm{g} / \mathrm{ml})$. $\mathrm{Km}^{\mathrm{r}}$ transconjugants were used as donors in triparental matings to determine mobilization of pPEC320::Tn5-Mob with $E$. coli HB101 containing helper plasmid pRK2013. Transconjugants were selected on VBG medium amended with Tp $(50 \mu \mathrm{g} / \mathrm{ml})$ and $\mathrm{Km}(600 \mu \mathrm{g} / \mathrm{ml}) . \mathrm{Tp}^{\mathrm{r}}$ recipient strains were constructed by mobilization of plasmid pSUP2017 into the strain and selection on VBG medium amended with Tp $(50 \mu \mathrm{g} / \mathrm{ml})$. In experiments that involved the mobilization of plasmid pPEC321 into derivatives of ATCC25416 as recipients, a Nal ${ }^{\mathrm{r}}$ recipient was used.

\section{Characterization of transconjugants.}

Parental strains and transconjugants were evaluated for Peh production on HA medium and M9GP broth and examined for plasmid content. Transconjugants were purified by serial colony isolation on medium containing selective antibiotic(s). Additionally, in matings that involved the transfer of pPEC321 from BCP strains to BCS or BCC recipients, the transconjugants were transferred to BSI and BSM media. Phytopathogenic B. cepacia strains used in this study were able to catabolize myo-inositol $\left(\right.$ ino $^{+}$) and not itaconic acid (ita), whereas the opposite was true for BCS and BCC strains. Colonies capable of catabolizing the substrate reduced the 2,3,5-triphenyltetrazolium chloride and produced a deep red formazan, whereas negative colonies remained colorless. The catabolic differences between the $\mathrm{BCP}$ and the $\mathrm{BCS}$ and $\mathrm{BCC}$ strains allowed confirmation of transconjugants that were of $\mathrm{BCS}$ or $\mathrm{BCC}$ recipient origin. HA medium plates incubated at 28 and $37^{\circ} \mathrm{C}$ were evaluated for pitting. Supernatants of 18 -h cultures were assayed as described below. To confirm the physical presence of the mobilized plasmid, agarose gel electrophoresis of the lysates of parental and recipient strains and transconjugants were conducted as previously described (Gonzalez and Vidaver 1979). Southern blots of the same gels were probed individually with a Tn5 probe (Jorgensen et al. 1979).

\section{Plant tissue maceration assay.}

Yellow onion cv. Texas $1015 \mathrm{Y}$ was used to determine the potential of strains to cause tissue maceration or necrosis. Onions were rinsed, and the outer bulb scales were removed in a manner that would not disturb the integrity of the bulb scale. Using a flame-sterilized knife, a transverse cut was made across the top and bottom of the bulb. The bulb was sectioned into four parts, and the outer bulb scale was discarded. The average bulb scale portion used was $3 \mathrm{~cm}$ wide and $7.5 \mathrm{~cm}$ long. The bulb scale portions were placed with the abaxial (inner) part of the scale up in a sterile glass petri dish lined with a Whatman (Maidstone, England) No. 1 filter paper that was kept moist with sterile deionized water. The plates were placed in a sealed plastic container to maintain moisture. The bulb scales were pierced at the center to just break the abaxial epidermal tissue with a blunted 18-gauge sterile needle. The bulb scales, replicates of four, were inoculated with $25 \mu \mathrm{l}$ of aqueous solution at a final concentration of $10^{3}$ or $10^{5} \mathrm{CFU}$ per bulb scale portion. Sterile deionized water was used as a negative control. Additionally, unwounded bulb scales treated with the inoculum were included as controls. The bulb scales were incubated at $37^{\circ} \mathrm{C}$ and evaluated for necrosis and maceration at 24 and $48 \mathrm{~h}$ after inoculation. Cultures to be assayed were grown at $37^{\circ} \mathrm{C}$ on $\mathrm{TN}$ agar containing the appropriate antibiotic as required.

\section{IEF and enzyme detection.}

Samples of supernatant concentrated 15- to 20-fold from cultures grown in M9GP medium were dialyzed against $1 \%$ glycine. The supernatant samples $(5 \mu \mathrm{l})$ and $\mathrm{pI}$ markers $(\mathrm{pH} 3$ to 10, Pharmacia LKB Biotechnologies, Piscataway, NJ) were applied to IsoGel agarose IEF plates (pH 3 to 10; FMC Corp., Rockland, MD) and electrofocused at $25 \mathrm{~W}$, with a $1,500-\mathrm{V}$ maximum, for 45 to $60 \mathrm{~min}$. Focusing was obtained when the visible $\mathrm{pI}$ markers were sharply resolved and the current stopped decreasing significantly (less than $1 \mathrm{~mA}$ in $10 \mathrm{~min}$ ). IEF was performed at $5^{\circ} \mathrm{C}$, using an Isobox model HE 950 (Hoefer Scientific Instruments, San Francisco). Pectolytic activity in IEF gels was determined by the method of Reid and Collmer (1985), using an ultrathin pectate-agarose overlay. The pI markers were stained with Coomassie, and agarose-pectate gels were stained with a $1 \%$ (wt/vol) solution of hexadecyltrimethylammonium bromide (Sigma).

\section{Enzyme activity.}

The endo or exo activity of the Peh from strain ATCC25416 on polygalacturonic acid was determined by analysis of the reaction products and examination of the rate of viscosity reduction. As controls, exo-poly- $\alpha$-D-galacturonidase and endopolygalacturonase were obtained by osmotic shock of strains DH5 $\alpha$ (pPEH10) (He and Collmer 1990) and DH10B(pCPP2068) (Herlache et al. 1997), respectively, grown for $18 \mathrm{~h}$ in LuriaBertani (LB) broth at $37^{\circ} \mathrm{C}$. The osmotic shock fluids were obtained as described below. Supernatant concentrates of ATCC25416 were obtained as for IEF experiments, except they were dialyzed against $50 \mathrm{mM}$ sodium acetate $(\mathrm{pH} \mathrm{5)}$ and $10 \mathrm{mM}$ EDTA. Conditions for the production of reducing groups incorporating the enzyme preparations were as described by Collmer et al. (1988). Negative controls consisted of enzyme preparations boiled for $10 \mathrm{~min}$. Samples $(200 \mu \mathrm{l})$ were removed from reactions (4 $\mathrm{ml})$ at 0 and $30 \mathrm{~min}$ and 1, 2, 4,8 , and $16 \mathrm{~h}$ and analyzed for the presence of reducing groups and hydrolytic products. Reducing groups were determined by the method of McFeeters (1980) and normalized to galacturonic acid equivalents. One unit of Peh activity was defined as 
the amount of enzyme that produces one mole of galacturonic acid equivalent per minute at $30^{\circ} \mathrm{C}$. Analysis of degradation products was determined by TLC, using thin-layer cellulose sheets (Baker-Flex, J. T. Baker Inc., Phillipsburg, NJ) that were developed for $7 \mathrm{~h}$ and allowed to air-dry and developed for an additional $7 \mathrm{~h}$ to obtain maximal separation in the solvent system described by Willis et al. (1987). Chromatography controls included D-galacturonic, digalacturonic, trigalacturonic, and polygalacturonic acids (Sigma). The products were visualized by the silver nitrate staining method as described by Hough and Jones (1962). $\mathrm{R}_{f}$ values were expressed as the ratio of cleavage product migration to the distance migrated by the D-galacturonic acid standard on each of the TLC plates. Changes in viscosity were determined at $30^{\circ} \mathrm{C}$, as described by Willis et al. (1987).

To determine whether the production of Peh was regulated in ATCC25416, cells were grown under noninducing conditions (M9 medium supplemented with $0.5 \%$ glucose), washed, and transferred to M9 medium supplemented with glucose or $0.5 \%$ polygalacturonic acid. Cell cultures $(5 \mathrm{ml})$ were harvested $\left(7,000 \times g\right.$ at $5^{\circ} \mathrm{C}$ for $\left.10 \mathrm{~min}\right)$ and resuspended in $1 \mathrm{ml}$ of assay buffer. Cell extracts were prepared by sonication with a Heat Systems (Farmington, NY) sonicator (model XL2005) at $50 \%$ full power, using three 30 -s pulses. The sonicate was centrifuged $\left(7,000 \times g\right.$ at $5^{\circ} \mathrm{C}$ for $\left.10 \mathrm{~min}\right)$ to remove cell debris. Supernatants and cell sonicates were assayed for activity by the method of Collmer et al. (1988). Reducing groups were determined by the method of McFeeters (1980) and normalized to galacturonic acid equivalents. Specific activity was expressed as micromoles of galacturonic acid equivalent per minute at $30^{\circ} \mathrm{C}$ per milligram of protein. Protein concentration was determined by the method of Koch and Putnum (1971).

\section{DNA analysis.}

Survey lysis of cells and agarose gel electrophoresis (Gonzalez and Vidaver 1979) were performed to determine plasmid content of temperature-induced $\mathrm{Peh}^{-}$derivatives and the parental strain. Alkaline Southern transfer of plasmid DNA from gels was performed as described by Reed and Munn (1985). Purified plasmid pRZ102 (ColE1 replicon containing Tn5) was labeled with $\left[{ }^{32} \mathrm{P}\right] \mathrm{d}$-ATP by the random primer method (Sambrook et al. 1989). The 2.8-kb EcoRI-BamHI insert from pPEC325 that contains pehA was isolated from low melt agarose, using Bio 101 (LaJolla, CA) Geneclean II kit according to the manufacturer protocol, and labeled in a similar manner.

\section{Cloning, subcloning, and restriction mapping.}

CsCl-ethidium bromide-purified plasmid pPEC320 DNA was digested with restriction enzyme SstI (Life Technologies, Gaithersburg, MD), and the resulting fragments were ligated into cosmid pUFRO34 (DeFeyter et al. 1990). The cosmid library was packaged in vitro into lambda-phage particles, using the Packagene system (Promega Corp., Madison, WI) according to the manufacturers instructions. A fraction of the phage suspension was used to infect E. coli $\mathrm{DH} 5 \alpha \mathrm{MCR}$ cells and $\mathrm{Km}^{\mathrm{r}}$ transductants selected on LB agar supplemented with isopropyl- $\beta$-D-thiogalactopyranoside (IPTG; Sigma), 5-bromo-4-chloro3 -indolyl- $\beta$-D-galactopyranoside (X-Gal; Sigma), and Km. Transductants containing recombinant cosmids were used as donors in triparental matings with pRK2013 and strain BCS20 as the recipient. Transconjugants were selected on VBG me- dium amended with $\mathrm{Km}$. The transconjugants were assayed for Peh activity on HA and M9GP media and for maceration of plant tissue as described above. Restriction mapping of the cosmids and plasmid was accomplished by standard methods (Sambrook et al. 1989).

\section{Transposon and marker-exchange mutagenesis.}

Transposon mutagenesis was accomplished with pHoKmGus by the procedure of Bonas et al. (1989). The mutagenized cosmids were mobilized into strain BCS20, using pRK2013, and tested for Peh activity. Production of $\beta$-glucuronidase activity by pHoKmGus was measured by the method of Jefferson (1987). Restriction mapping of the pHoKmGus inserts was accomplished by standard methods (Sambrook et al. 1989). For marker exchange, derivatives of pPEC325 containing the pHoKmGus insertions in the structural gene were mobilized into strain ATCC25416. To facilitate marker exchange, transconjugants were transferred for several cycles on TN agar without antibiotic selection. Marker-exchanged isolates were $\mathrm{Km}^{\mathrm{r}}$ and $\mathrm{Gm}^{\mathrm{s}}$. The mutants were assayed for Peh activity with HA medium, tested for activity on plant material, and used as donors in self-transfer experiments. The location of the insertion was confirmed by Southern blot analysis of plasmid DNA prepared from the mutants with a Tn5 probe.

\section{Secretion analysis.}

Supernatants of 18-h cultures of B. cepacia strains grown in M9GP medium at $28^{\circ} \mathrm{C}$ and shaken at $250 \mathrm{rpm}$ (model 4710 , Queue Systems) were filtered $(0.22 \mu \mathrm{m})$, and a $10-\mu \mathrm{l}$ sample was spotted on a pectate-agarose gel $(50 \mathrm{mM}$ potassium acetate, $\mathrm{pH} 4.5$ ) (Reid and Collmer 1985). After $1 \mathrm{~h}$ at $28^{\circ} \mathrm{C}$, the gel was stained with ruthenium red. A clear zone was indicative of Peh activity. For analysis of excretion by $P$. aeruginosa, PAO25 and PAO25(pPEC324) cells were grown at $37^{\circ} \mathrm{C}$ (200 rpm; model G76, New Brunswick Scientific) in M9GP medium supplemented with leucine and arginine $(0.50 \mathrm{mM})$. After $18 \mathrm{~h}$, the cultures were concentrated by centrifugation $\left(7,000 \times g\right.$ at $5^{\circ} \mathrm{C}$ for $\left.10 \mathrm{~min}\right)$, and the supernatant was saved. The cells were washed twice in $10 \mathrm{mM}$ Tris- $\mathrm{HCl}(\mathrm{pH} 7.0)$ containing $20 \%$ sucrose. The washed cells were resuspended in one-half volume of the same buffer containing $5 \mathrm{mM}$ EDTA and held on ice for $10 \mathrm{~min}$. The cells were centrifuged as described previously and resuspended in $1 / 20$ volume of $0.5 \mathrm{mM}$ $\mathrm{MgCl}_{2}$. The suspension was held on ice for $10 \mathrm{~min}$, centrifuged, and supernatant (osmotic shock fluid) collected. Extracellular and periplasmic enzyme activities were determined from the culture supernatant and osmotic shock fluid, respectively, using the pectate gel assay. Strains PAO25, BCP251, and BCP252 (negative controls) were analyzed under the same conditions.

\section{Nucleotide sequence.}

The 2.85-kb EcoRI-BamHI fragment from pPEC324 was cycle sequenced with SequiTherm polymerase (Epicentre Technologies, Madison, WI) as described by the manufacturer. Both strands were sequenced. The sequence was determined with oligonucleotide primers overlapping previously sequenced portions of the fragment. The primers used were constructed by the Gene Technology Laboratory, Texas A\&M University, College Station. Similar sequences were identified by the BLAST network service (Atschul et al. 1990) at the National Center 
for Biotechnology Information, Bethesda, MD. Sequence comparisons were done with the BESTFIT program and the multiple sequence alignment with the PILEUP program from the University of Wisconsin Genetics Computer Group (Devereux et al. 1984).

\section{ACKNOWLEDGMENTS}

We thank D. Ebbole and D. Cook for critically reading the manuscript. We also thank R. DeFeyter and D. Gabriel for providing the pUFR0 vectors critical to this study.

\section{LITERATURE CITED}

Allen, C., Haung, Y., and Sequeira, L. 1991. Cloning of genes affecting polygalacturonase production in Pseudomonas solanacearum. Mol. Plant-Microbe Interact. 4:147-154.

Atschul, S. F., Gish, W., Miller, W., Myers, E. W., and Lipman, D. J. 1990. Basic local alignment search tool. J. Mol. Biol. 215:403-410.

Ballard, R. W., Palleroni, N. J., Doudoroff, M., Stanier, R. Y., and Mandel, M. 1970. Taxonomy of the aerobic pseudomonads: Pseudomonas cepacia, P. marginata, P. alliicola, and P. caryophylli. J. Gen. Microbiol. 60:199-214

Barras, F., van Gijsegem, F., and Chatterjee, A. K. 1994. Extracellular enzymes and pathogenesis of soft-rot Erwinia. Annu. Rev. Phytopathol. 32:201-234.

Barsomian, G., and Lessie, T. G. 1986. Replicon fusions promoted by insertion sequences on Pseudomonas cepacia plasmid pTGL6. Mol. Gen. Genet. 204:273-280.

Beckman, W., Gaffney, T., and Lessie, T. G. 1982. Correlation between auxotrophy and plasmid alteration in mutant strains of Pseudomonas cepacia. J. Bacteriol. 149:1154-1158.

Bird, C. R., Smith, C. J., Ray, J. A., Moureau, P., Bevan, M. W., Bird, A. S., Hughes, S., Morris, P. C., Grierson, D., and Schuch, W. 1988. The tomato polygalacturonase gene and ripening-specific expression in transgenic plants. Plant Mol. Biol. 11:651-662.

Bochner, B. R., and Savageau, M. A. 1977. Generalized indicator plate for genetic, metabolic, and taxonomic studies with microorganisms. Appl. Environ. Microbiol. 33:434-444.

Bonas, U., Stall, R., and Staskawicz, B. 1989. Genetic and structural characterization of the avirulence gene avrBs 3 from Xanthomonas campestris pv. vesicatoria. Mol. Gen. Genet. 218:127-136.

Boyer H. W., and Roulland-Dussoix, D. 1969. A complementation analysis of the restriction and modification DNA in Escherichia coli. J. Mol. Biol. 41:459-465.

Burkholder, W. H. 1950. Sour skin, a bacterial rot of onion bulbs. Phytopathology 40:115-117.

Bussink, H. J. D., Buxton, F. P., and Visser, J. 1991. Expression and sequence comparison of the Aspergillus niger and Aspergillus tubigensis genes encoding polygalacturonase II. Curr. Genet. 19:467-474.

Collmer, A., Bauer, D. W., He, S. Y., Lindeberg, M., Kelemu, S., Rodriguez-Palenzuala, P., Burr, T., and Chatterjee, A. K. 1990. Pectic enzyme production and bacterial pathogenicity. Pages 65-72 in: Advances in Molecular Genetics of Plant-Microbe Interactions. Vol. 1. H. Hennecke and D. P. S. Verma, eds. Kluwer Academic Publishers, Dordrecht, the Netherlands.

Collmer, A., and Keen, N. T. 1986. The role of pectic enzymes in plant pathogenesis. Annu. Rev. Phytopathol. 24:383-409.

Collmer, A., Ried, J. L., and Mount, M. S. 1988. Assay methods for pectic enzymes. Methods Enzymol. 161:329-335.

Conly, J. M., Klass, L., Larson, L., Kennedy, J., Low, D. E., and Harding, G. K. M. 1986. Pseudomonas cepacia colonization and infection in intensive care units. Can. Med. Assoc. J. 134:363-366.

Cooke, R. D., Ferber, C. E. M., and Kanagasabapathy, L. 1976. Purification and characterization of polygalacturonase from a commercial Aspergillus niger preparation. Biochim. Biophys. Acta 452:440-451.

Cother, E. J., and Dowling, V. 1985. Association of Pseudomonas cepacia with internal breakdown of onion: A new record of Australia. Australas. Plant Pathol. 14:10-12.

DeFeyter, R., and Gabriel, D. W. 1991. At least six avirulence genes are clustered on a 90-kilobase plasmid in Xanthomonas campestris pv. malvacearum. Mol. Plant-Microbe Interact. 4:423-432.
DeFeyter, R., Kado, C. I., and Gabriel, D. W. 1990. Small, stable shuttle vectors for use in Xanthomonas. Gene 88:65-72.

Devereux, J., Haeberli, P., and Smithies, O. 1984. A comprehensive set of sequence analysis programs for VAX. Nucleic Acids Res. 12:387395.

Figurski, D., and Helinski, D. R. 1979. Replication of an origin-containing derivative of plasmid RK2 dependent on a plasmid function provided in trans. Proc. Natl. Acad. Sci. USA 76:1648-1652.

Gaffney, T. D., and Lessie, T. G. 1987. Insertion-sequence-dependent rearrangements of Pseudomonas cepacia plasmid pTGL1. J. Bacteriol. 169:224-230.

Gonzalez, C. F., and Vidaver, A. K. 1979. Bacteriocin, plasmid, and pectolytic diversity in Pseudomonas cepacia of clinical and plant origin. J. Gen. Microbiol. 110:161-170.

Grierson, D., Tucker, G. A., Keen, J., Ray, J., Bird, C. R., and Schuch, W. 1986. Sequencing and identification of a cDNA clone for tomato polygalacturonase. Nucleic Acids Res. 21:8595-8603.

Gross, D. C., and Cody, Y. S. 1985. Mechanisms of plant pathogenesis by Pseudomonas species. Can. J. Microbiol. 31:403-410.

Hansen, J. B., and Olsen, R. H. 1978. Isolation of large bacterial plasmids and characterization of the $\mathrm{P} 2$ incompatibility group plasmids pMG1 and pMG5. J. Bacteriol. 135:227-238.

He, S. Y., and Collmer, A. 1990. Molecular cloning, nucleotide sequence, and marker-exchange mutagenesis of the exo-poly- $\alpha$-D-galacturonosidase-encoding pehX gene in Erwinia chrysanthemi EC16. J. Bacteriol. 172:4988-4995.

Herlache, T. C., Hotchkiss, A. T., Burr, T. J., and Collmer, A. 1997. Characterization of the Agrobacterium vitis pehA gene and comparison of the encoded polygalacturonase with the homologous enzymes from Erwinia carotovora and Ralstonia solanacearum. Appl. Environ. Microbiol. 63:338-346.

Hildebrand, D. C. 1971. Pectate and pectin gels for differentiation of Pseudomonas sp. and other bacterial plant pathogens. Phytopathology 61:1430-1436.

Hough, L., and Jones, J. K. N. 1962. Chromatography on paper. Pages 21-31 in: Methods in Carbohydrate Chemistry. Vol. 1, Analysis and Preparation of Sugars. R. L. Whistler and M. L. Wolfrom, eds. Academic Press, New York.

Huang, J., and Schell, M. 1990. DNA sequence analysis of pglA and mechanism of export of its polygalacturonase product from Pseudomonas solanacearum. J. Bacteriol. 172:3879-3887.

Jefferson, R. A. 1987. Assaying chimeric genes in plants: The GUS gene fusion system. Plant Mol. Biol. Rep. 5:387-405.

Jorgensen, R. A., Rothstein, S. J., and Reznikoff, W. S. 1979. A restriction enzyme cleavage map of $\operatorname{Tn} 5$ and location of a region encoding neomycin resistance. Mol. Gen. Genet. 177:65-72.

Kawamoto, S. O., and Lorbeer, J. W. 1972. Multiplication of Pseudomonas cepacia in onion leaves. Phytopathology 62:1263-1265.

Kawamoto, S. O., and Lorbeer, J. W. 1974. Infection of onion leaves by Pseudomonas cepacia. Phytopathology 64:1440-1445.

Koch, A., and Putnam, S. 1971. Sensitive biuret method for the determination of protein in an impure system such as whole bacteria Anal. Biochem. 44:237-245.

Lennon, E., and DeCicco, B. T. 1991. Plasmids of Pseudomonas cepacia strains of diverse origins. Appl. Environ. Microbiol. 57:2345-2350.

Lessie, T. G., Wood, M. S., Byrne, A., and Ferrante, A. 1990. Transposon gene-activating elements in Pseudomonas cepacia. Pages 279291 in: Pseudomonas: Biotransformations, Pathogenesis, and Evolving Biotechnology. S. Silver, A. M. Chakrabarty, B. Iglewski, and S. Kaplan, eds. American Society for Microbiology, Washington D.C.

McArthur, J. V., Kovacic, D. A., and Smith, M. H. 1988. Genetic diversity in natural populations of a soil bacterium across a landscape gradient. Proc. Natl. Acad. Sci. USA 85:9621-9624.

McFeeters, R. F. 1980. A manual method for reducing sugar determination with 2,2'-bicinchoninate reagent. Anal. Biochem. 103:302-306.

McKevitt, A. I., and Woods, D. E. 1984. Characterization of Pseudomonas cepacia isolates from patients with cystic fibrosis. J. Clin. Microbiol. 19:291-293.

Mermod, N., Lehbach, P. R., Reineke, W., and Timmis, K. N. 1984. Transcription of the TOL plasmid toluate catabolic pathway operon of Pseudomonas putida is determined by a pair of co-ordinately and positively regulated overlapping promoters. EMBO J. 3:2461-2466.

Murata, H., Fons, M., Chatterjee, A., Collmer, A., and Chatterjee, A. K. 1990. Characterization of transposon insertion $\mathrm{Out}^{-}$mutants of $\mathrm{Er}$ - 
winia carotovora subsp. carotovora defective in enzyme export and of a DNA segment that complements out mutations in E. carotovora subsp. carotovora, E. carotovora subsp. atroseptica, and Erwinia chrysanthemi. J. Bacteriol. 172:2970-2978.

Reed, K. C., and Munn, D. A. 1985. Rapid transfer of DNA from agarose gels to nylon membranes. Nucleic Acids Res. 13:7207-7221.

Reid, J. L., and Collmer, A. 1985. Activity stain for rapid characterization of pectate enzymes in isoelectric focusing and sodium dodecyl sulfate-polyacrylamide gels. Appl. Environ. Microbiol. 50:615-622.

Saarilahti, H. T., Heino, P., Pakkanen, R., Kalkkinen, N., Palva, I., and Palva, E. T. 1990. Structural analysis of the pehA gene and characterization of its protein product, endopolygalacturonase, of Erwinia carotovora subspecies carotovora. Mol. Microbiol. 4:1037-1044.

Salmond, G. P. C. 1994. Secretion of extracellular virulence factors by plant pathogenic bacteria. Annu. Rev. Phytopathol. 32:181-200.

Sambrook, J., Fritsch, E. F., and Maniatis, T. 1989. Molecular Cloning: A Laboratory Manual. 2nd ed. Cold Spring Harbor Laboratory Press, Cold Spring Harbor, NY.

Schell, M. A., Roberts, D. P., and Denny, T. P. 1988. Analysis of the Pseudomonas solanacearum polygalacturonase encoded by pglA and its involvement in phytopathogenicity. J. Bacteriol. 170:4501-4508.

Scordilis, G., Ree, E. H., and Lessie, T. G. 1987. Identification of transposable elements which activate gene expression in Pseudomonas cepacia. J. Bacteriol. 169:8-13.

Simon, R. 1984. High frequency mobilization of gram-negative bacterial replicons by the in vitro constructed Tn5-Mob transposon. Mol. Gen. Genet. 196:413-420.

Simon, R., Priefer, U., and Puhler, A. 1983. A broad host range mobilization system for in vitro genetic engineering: Transposon mutagenesis in gram-negative bacteria. Biotechnology 1:784-791.

Stachel, S. E., An, G., Flores, C., and Nester, E. W. 1985. A Tn3 lacZ transposon for the random generation of $\beta$-galactosidase gene fusion: Application to the analysis of gene expression in Agrobacterium. EMBO J. 4:891-898.

Stratilova, E., Dzurova, M., Markovic, O., and Jornvall, H. 1996. An es- sential tyrosine residue of Aspergillus polygalacturonase. FEBS Lett. 382:164-166.

Tablan, O. C., Martone, W. J., Doershuk, C. F., Stern, R. C., Thomassen, M. J., Klinger, J. D., White, J. W., Carson, L. A., and Jarvis, W. R. 1987. Colonization of the respiratory tract with Pseudomonas cepacia in cystic fibrosis: Risk factors and outcomes. Chest 91:527-532.

Ulrich, J. M. 1975. Pectic enzymes of Pseudomonas cepacia and penetration of polygalacturonase into cells. Physiol. Plant Pathol. 5:37-44.

Vogel, H. J., and Bonner, D. M. 1965. Acetylornithinase of E. coli partial purification and some properties. J. Biol. Chem. 281:97-106.

von Heijne, G. 1985. Signal sequences the limits of variation. J. Mol. Biol. 184:99-105.

von Heijne, G. 1986. A new method for predicting signal sequence cleavage sites. Nucleic Acids Res. 14:4683-4690.

Willis, J. W., Engwall, J. K., and Chatterjee, A. K. 1987. Cloning of genes for Erwinia carotovora subsp. carotovora pectolytic enzymes and further characterization of the polygalacturonases. Phytopathology 77:1199-1205.

Wood, M. S., Lory, C., and Lessie, T. G. 1990. Activation of the lac genes of Tn951 by insertion sequences from Pseudomonas cepacia. J. Bacteriol. 172:1719-1724.

Yabauuchi, E., Kosako, Y., Oyaizu, H., Yano, I., Hotta, H., Hashimoto, Y., Ezaki, T., and Arakawa, M. 1992. Proposal of Burkholderia gen. nov. and transfer of seven species of the genus Pseudomonas homology group II to the new genus, with the type species Burkholderia cepacia (Palleroni and Holmes 1981) comb. nov. Microbiol. Immunol. 36:12511275.

Yabauuchi, E., Kosako, Y., Yano, I., Hotta, H., and Nishiuki, Y. 1995. Transfer of two Burkholderia and an Alcaligenes species to Ralstonia gen. nov.: Proposal of Ralstonia pickettii (Ralston, Palleroni and Duodoroff 1973) comb. nov. and Ralstonia eutropha (Davis 1969) comb. nov. Microbiol. Immunol. 39:897-904.

Zylstra, G. J., Olsen, R. H., and Ballou, D. P. 1989. Cloning, expression, and regulation of the Pseudomonas cepacia protocatecuate 3,4-deoxygenase genes. J. Bacteriol. 171:5907-5914.

\section{Erratum, Vol. 10, no. 7, 1997}

An article by C. F. Gonzalez et al. (10:840-851) entitled "Mobilization, Cloning, and Sequence Determination of a PlasmidEncoded Polygalacturonase from a Phytopathogenic Burkholderia (Pseudomonas) cepacia" contained errors in the footnotes of Table 3. The corrected table appears below.

Table 3. Onion tissue maceration and/or necrosis by Burkholderia cepacia strains

\begin{tabular}{lcc}
\hline & \multicolumn{2}{c}{ Inoculum (CFU/bulb scale) } \\
\cline { 2 - 3 } Strain & $\mathbf{1 0}^{\mathbf{3}}$ & $\mathbf{1 0}^{\mathbf{5}}$ \\
\hline ATCC25416 & $26 \pm 3.2^{\mathrm{a}, \mathrm{b}}$ & $29 \pm 4^{\mathrm{a}, \mathrm{b}}$ \\
BCP252 & $8.3 \pm 1^{\mathrm{c}}$ & $10.3 \pm 2^{\mathrm{c}}$ \\
BCC10 & $0^{\mathrm{a}, \mathrm{c}}$ & $7.7 \pm 1.1^{\mathrm{c}}$ \\
BCC101 & $9.5 \pm 3^{\mathrm{a}, \mathrm{b}}$ & $16 \pm 5^{\mathrm{a}, \mathrm{b}}$ \\
BCS20 & $0^{\mathrm{a}, \mathrm{c}}$ & $0^{\mathrm{a}, \mathrm{c}}$ \\
BCS201 & $0^{\mathrm{a}, \mathrm{c}}$ & $0^{\mathrm{a}, \mathrm{c}}$ \\
\hline
\end{tabular}

${ }^{a}$ Number indicates the average macerating diameter (in millimeters) plus/ minus the standard deviation at $48 \mathrm{~h}$ for four replicates.

${ }^{\mathrm{b}}$ No necrosis was measurable due to masking by tissue maceration.

${ }^{c}$ Number indicates the average necrosis diameter (in millimeters) plus/ minus the standard deviation at $48 \mathrm{~h}$ for four replicates. 